\title{
Multicoloniality in the highly polygynous ant Crematogaster pygmaea (Formicidae: Myrmicinae)
}

\author{
Rachid HAMIDI ${ }^{1}$, Gabriel DEBOUT $^{2 *}$, Ana HEREDIA $^{3}$, Denis FOURNIER ${ }^{4}$, Yves QUINET $^{5}$ \\ and JEAN-ChristOPHE DE BISEAU ${ }^{6}$

\begin{abstract}
1,2,4,6 Evolutionary Biology and Ecology, CP 160 / 12, Université Libre de Bruxelles, Avenue F.D. Roosevelt 50, B-1050 Brussels, Belgium; e-mails: ${ }^{1}$ rachid.hamidi@ulb.ac.be, ${ }^{2}$ debout@cict.fr, ${ }^{4}$ denis.founier@ulb.ac.be, ${ }^{6}$ jcbiseau@ulb.ac.be

${ }^{3,5}$ Laboratório de Entomologia, Instituto Superior de Ciências Biomédicas, Universidade Estadual do Ceará, 60740-000 Fortaleza, Brazil, e-mails: ${ }^{3}$ heredia.a@gmail.com, ${ }^{5}$ yvesq@terra.com.br
\end{abstract}

Key words. Formicidae, Myrmicinae, multicoloniality, polygyny, polydomy, Crematogaster pygmaea, context-dependent nestmate discrimination

\begin{abstract}
In social insects, the high variability in the number of queens per colony raises fundamental questions about the evolution of altruism. It is hypothesized, for instance, that nestmate recognition should be less efficient in polygynous than in monogynous colonies because the presence of several breeders increases the diversity of genetically determined recognition cues, leading to a less specific colonial signature. Recent studies, however, have shown that the link between the number of queens in a colony and the recognition abilities of its members is more complex than previously suggested. Here, we studied intraspecific aggression, diversity of potential recognition cues and genetic structure of colonies in the highly polygynous ant Crematogaster pygmaea. Our results reveal that workers of this species are clearly aggressive towards non-nestmates in field experiments but not in more artificial bioassays conducted in Petri dishes, underscoring the importance of context-dependent aspects of the assessment of nestmate recognition. Behavioural, genetic and chemical data show that C. pygmaea is a multicolonial species, forming spatially restricted and welldefined entities. Therefore, the postulated negative correlation between recognition ability of workers and queen number in a colony is not supported by the results of this study.
\end{abstract}

\section{INTRODUCTION}

In social insects, nestmate recognition is essential to ensure the cohesion of the colony. In monogynous and monoandrous species, nestmate recognition leads to particularly efficient kin discrimination since all members of the colony are closely related. Therefore, nestmate recognition is an efficient mechanism allowing the evolution of altruism by kin selection (Hamilton, 1964a, b; Crozier \& Pamilo, 1996). However, colonies with several queens are frequently recorded in social insects, particularly ants (Bourke \& Franks, 1995), and polygyny is generally associated with a lower relatedness among nestmate workers and constitutes a major evolutionary paradox (Keller, 1995).

It is hypothesized that the presence of several queens in the same colony may decrease the recognition ability of the workers and the specificity of the colony odour, leading to a reduced aggressiveness towards foreign individuals (Bourke \& Franks, 1995). Several studies have confirmed that nestmate recognition is less efficient in polygynous than in monogynous colonies and/or that polygynous colonies are less aggressive than monogynous ones (e.g. Linepithema humile: Keller \& Passera, 1989; Solenopsis invicta: Morel et al., 1990; Messor barbarus: Provost \& Cerdan, 1990, Pseudomyrmex pallidus: Starks et al., 1998). In several highly polygynous species forming large unicolonial structures or super-colonies, aggression between workers from relatively distant nests is completely absent (e.g. Tsutsui et al., 2000; Holway et al., 2002). Some studies, however, have shown that the negative correlation between the number of queens in a colony and its tolerance towards non-nestmates is not a rule (e.g. Leptothorax ambiguous: Stuart, 1991; Camponotus yamaokai: Satoh \& Hirota, 2005; Formica selysi: Rosset et al., 2007; Myrmica rubra: Garnas et al., 2007; Dolichoderus mariae: Laskis \& Tschinkel, 2008). Moreover, most polygynous ant species are territorial. Even in highly polgynous species, aggression is observed between workers belonging to different super-colonies (e.g. Vogel et al., 2009; Drescher et al., 2010). The relationship between social structure (monogynous vs. polygynous) and colony closure in ants is therefore more complex than previously suggested.

Living along the North-East coast of Brazil, Crematogaster pygmaea (Forel, 1904) is a terricolous species which forms large polydomous colonies (Quinet et al., 2009). Each colony is formed by dozens of nests (each comprising 1 to 4 chambers) dug in the ground and covering about $250 \mathrm{~m}^{2}$. Each nest opens at the soil surface and all the entries of a colony are interconnected by a network of trails on the surface. A queen/worker ratio, reaching 1/100 (Quinet et al., 2009), is similar to that found in tramp species such as L. humile, Monomorium pharaonis or Wasmannia auropunctata (Passera, 1994).

* This paper is dedicated to his memory. 
In this study, we investigated intraspecific aggressiveness within the highly polygynous ant $C$. pygmaea, using both classic laboratory confrontations and field observations, to test for the presence of multicoloniality in this species. In order to locate colony boundaries, chemical and genetic analyses were also performed. These analyses enabled us to estimate the variability in potential recognition cues associated with different nests, the genetic structure of the colonies and the relationships between these parameters and both patterns of aggression and spatial data.

\section{MATERIAL AND METHODS}

\section{Populations and colonies studied}

Because of the occurrence of polydomy in this species (sensu Debout et al., 2007), colony boundaries were not easy to determine. In this paper, the term "nest" will be used to refer to a group of 1-4 chambers in the soil that have a single common entrance at the soil surface (Quinet et al., 2009). A colony is defined as several nests interconnected by a network of trails on which workers were regularly observed moving from one nest to another. Occasionally, brood carried by workers and queens were also observed moving along the trails. Two nests were considered as belonging to two different colonies if trails were never observed between them. Populations are defined as groups of colonies separated by a clear physical barrier (an urban zone for instance) or a distance greater than $10 \mathrm{~km}$.

Twelve populations of $C$. pygmaea, designated POP-1 to POP-12, were chosen for the present study. Five of them (POP-1 to 4, and POP-10; distance between colonies: mean \pm $\mathrm{SE}=80 \pm 4 \mathrm{~m}$ ) were located on or near the campus of the State University of Ceará, in Fortaleza (north eastern Brazil). The other seven populations were situated 10 to $243 \mathrm{~km}$ away from the campus (Fig. 1). In each population, two colonies were selected for field experiments and laboratory analysis (distance between colonies: mean $\pm \mathrm{SE}=62.73 \pm 37.17 \mathrm{~m}$ ).

\section{Aggression tests}

Aggressiveness towards individuals from other colonies was first assessed by observing dyadic encounters between two workers of $C$. pygmaea in a neutral arena $(5 \mathrm{~cm}$ diameter Petri dish with fluon-coated sides). For this purpose, laboratory colonies were obtained from 6 populations (POP-1, POP-3, POP-5, POP-6, POP-9 and POP-11). These 6 colonies were stored in plastic nest boxes $(230 \mathrm{~mm} \times 180 \mathrm{~mm} \times 40 \mathrm{~mm}$ with fluoncoated sides) provided with several nest tubes and were maintained under natural light and temperature.

Ants were fed twice a week with dilute sugar $(\sim 0.25 \mathrm{M}$ sucrose solution), water and dry cat food (PURINA@ FIT32). The colonies were kept in the laboratory for a maximum of 3 days before performing the aggression tests. During each experimental encounter between two workers originating from the same colony (POP-1) (control, $\mathrm{N}=20$ ) or from two different colonies (POP-1, POP-3, POP-5, POP-6, POP-9 and POP-11) $(\mathrm{N}=20$ for each of the 11 pairs of colonies tested), the behaviour of the workers and the time spent in antennation were recorded for $5 \mathrm{~min}$. All the workers tested were collected in the foraging area of laboratory colonies. The encounter was scored as aggressive if at least one of the following interactions was observed during the $5 \mathrm{~min}$ period: grips (from $1 \mathrm{~s}$ to several minutes), strong gaster flexions with or without application of defensive secretion, prolonged bites (see Marlier et al., 2004 and Quinet et al., 2005 for a detailed description of typical defensive behaviour of Crematogaster ants). After each experiment, the
Petri dish was carefully cleaned with $90^{\circ} \mathrm{C}$ ethanol and dried to remove any chemical signals left by the workers.

A second set of experiments was carried out in the field (eleven populations studied, POP 9 was not used). In each behavioural assay, one worker (the intruder) was carefully placed on the trail of a resident colony, $10 \mathrm{~cm}$ from a nest entrance and the interactions between the intruder and the residents were scored for $5 \mathrm{~min}$. The same behaviour as described above was used to define aggression. Workers that were not attacked after 5 min were considered as adopted by the resident colony. Generally, 10 to 30 contacts were sufficient to establish the nature of the interaction (aggression or adoption). For each pair wise test there were 20 replicates with at least $5 \mathrm{~min}$ between two consecutive replicates. Colonies were chosen in order to test (i) the intra-colonial aggressiveness (between nests of the same colony, $\mathrm{N}=22$ ), (ii) inter-colonial aggressiveness (between 2 colonies from the same population, $\mathrm{N}=11$ ) and (iii) inter-population aggressiveness (between colonies from different populations, $\mathrm{N}=10$, in this case POP- 1 was the resident population in all the replicates) (Fig. 2). Control experiments consisted of removing a worker from a trail and reintroducing it on the same trail $4 \mathrm{~s}$ later $(\mathrm{N}=22)$.

\section{Extraction of cuticular lipids and chemical analyses}

Immediately after field confrontations, samples of 40 workers from each nest or colony tested were immersed in $300 \mu \mathrm{l}$ of hexane for $15 \mathrm{~min}$ and the liquid stored until required for analysis. Cuticular lipids were analyzed by GC/MS using a Finnigan Polaris $\mathrm{Q}^{\mathrm{TM}}$ ion trap mass spectrometer interfaced with a Trace GC Ultra ${ }^{\mathrm{TM}}$ gas chromatograph equipped with a DB-5MS fused silica capillary column $(30 \mathrm{~m} \times 0.25 \mathrm{~mm}$ diameter $\times 0.25 \mu \mathrm{m}$ film thickness) from $\mathrm{J} \& \mathrm{~W}$ Scientific. The injection port and transfer line were set at $240^{\circ} \mathrm{C}$ and $310^{\circ} \mathrm{C}$, respectively. Following splitless injection of $1 \mu \mathrm{l}$ of the sample, oven temperature was maintained at $80^{\circ} \mathrm{C}$ for two min, increased to $270^{\circ} \mathrm{C}$ at $20^{\circ} \mathrm{C} / \mathrm{min}$ and then to $310^{\circ} \mathrm{C}$ at $3^{\circ} \mathrm{C} / \mathrm{min}$, using helium as the carrier gas $(1.2 \mathrm{ml} / \mathrm{min})$. Qualitative and quantitative data were acquired by running the Thermo Finnigan Xcalibur ${ }^{\mathrm{TM}}$ 1.4. SR1 data system. Cuticular lipids were identified by analysing their mass spectra produced either by electron impact (ion source operating at $150^{\circ} \mathrm{C}$ with an ionization energy of $70 \mathrm{eV}$, scan range $\mathrm{m} / \mathrm{z} 40-700$ ) or chemical ionization (ion source operating at $200^{\circ} \mathrm{C}$, methane as reagent gas $[0.3 \mathrm{ml} / \mathrm{min}]$, scan range $\mathrm{m} / \mathrm{z}$ 40-700) and by comparing their GC retention times with those of reference compounds (Alkanes-mix 10: C10 to C35, Dr. Ehrenstorfer Gmbh). The proportions of the different compounds were obtained from peak areas. The Nei index was used to estimate the degree of similarity between cuticular profiles:

$$
I=\frac{\sum^{n} X_{i} * Y_{i}}{\sqrt{\sum^{n} X_{i}^{2} * \sum^{n} Y_{i}^{2}}}
$$

where $n$ is the number of peaks, $X_{i}$ the area (\%) of peak $i$ for sample $x$, and $Y_{i}$ the area (\%) of peak $i$ for sample $y$. For two strictly identical profiles we have $I=1$, and $I=0$ for two totally different profiles. To calculate the Nei index (using $R$ software, http://cran.r-project.org/), we excluded the peaks with a relative peak area of less than $3 \%$ in all cuticular profiles.

A Mantel test was used to estimate the association between chemical differentiation and geographical distance between all pairs of samples. The matrix correlation and the correlation coefficient test were obtained using, respectively, GeneAlex 6.2 (Peakall \& Smouse, 2006) and GraphPad Instat 3.06 software (GraphPad Software, San Diego California USA). 


\section{Isolation of polymorphic microsatellite loci}

A genomic library was constructed and then enriched for microsatellite loci following a protocol similar to the one described by Glenn \& Schable (2005). Briefly, genomic DNA was extracted from $C$. pygmaea workers using a standard phenol/chloroform extraction protocol (Sambrook et al., 1989). Genomic DNA was restricted with Sau3AI. Restricted fragments were ligated at both ends to a double-stranded linker that was used later as primer-binding site for PCR amplification. The ligation product was run on a $1 \%$ agarose gel and fragments of size $800-1,200$ bp were extracted and purified with the Qiaquick Gel Extraction Kit (QIAGEN). Hybridization of fragmented and denatured genomic DNA (gDNA) with different microsatellite biotinylated oligonucleotide probes was conducted at different temperatures in the presence of streptavidincoated magnetic beads. The hybrid gDNA/oligonucleotide probes were isolated using a magnet and the hybridized gDNA was recovered through a series of washing steps. The product of this procedure was PCR amplified (using primers binding to the previously added linkers) with the Long Expand Template PCR System Kit (Roche), and PCR products were ligated to the $p$ STC1.3 no-background vector (StabyCloning ${ }^{T M}$ kit, Delphi Genetics) and transformed into competent cells (Delphi Genetics). Recombinant molecules were isolated from clones and sequences of inserted genomic DNA fragments were obtained by cycle sequencing followed by electrophoresis on an $\mathrm{ABI}$ 3730 sequencer (Applied Biosystems). Of the loci isolated, 45 were selected on the basis of their length (8-55 repetitions) and tested for polymorphism by genotyping several individuals from different populations. Finally, 4 loci that were sufficiently variable and had unambiguous amplification patterns were selected for genotyping workers from each population.

\section{DNA isolation and microsatellite genotyping}

Immediately after field confrontations, samples of workers from each nest tested (or colonies) were stored in absolute ethanol for subsequent genetic analyses. DNA was extracted from 16 workers per colony (mean $\pm \mathrm{SE}$ per nest $=7.11 \pm 2.85$ ), using a standard phenol/chloroform protocol. Genotype for each individual was determined for four polymorphic microsatellites.

Departures from Hardy-Weinberg equilibrium could be indicative of null alleles. The presence of alleles is readily detected in haploid males because they are not masked by the presence of another allele (Schrempf et al., 2005; Sandrock et al., 2007). Sixteen males ( 8 from POP-1 and 8 from POP-3) were genotyped in order to exclude the possibility of null alleles.

Amplifications were carried out in a $11.05 \mu \mathrm{l}$ volume containing $1 \mu \mathrm{l}$ of template DNA $(\sim 1 \mu \mathrm{g}$ per reaction), $0.2 \mu \mathrm{l}$ dNTPs $(10 \mathrm{mM}), 0.40 \mu \mathrm{l}$ of each Cpyg primer $(25 \mu \mathrm{M}), 6 \mu \mathrm{l}$ $\mathrm{H}_{2} \mathrm{O}$ Mili-Q, $2 \mu$ l Q-Solution (QIAGEN), $1 \mu \mathrm{l}$ Taq buffer (including $6 \mathrm{mM} \mathrm{MgCl}^{2}$ ) and $0.05 \mu \mathrm{l}$ Top $\mathrm{Taq}^{\mathrm{TM}} \mathrm{DNA}$ Polymerase (QIAGEN). Reactions were performed on a PTC-200 thermal cycler (MJ Research). After an initial denaturing step of $3 \mathrm{~min}$ at $94^{\circ} \mathrm{C}$, the PCR consisted of 35 cycles of $30 \mathrm{~s}$ at $94^{\circ} \mathrm{C}, 30 \mathrm{~s}$ at $60^{\circ} \mathrm{C}$ (annealing temperature) and $1 \mathrm{~min}$ at $72^{\circ} \mathrm{C}$. The length of the PCR products was determined using an ABI 3100 automated sequencer (Applied Biosystems) and Genemapper software (Applied Biosystems), in order to construct a multilocus genotype for each individual.

\section{Microsatellite data analyses}

Loci (from all our dataset) were examined for linkage disequilibrium using GENEPOP 3.4 on the Web (Raymond \& Rousset, 1995).

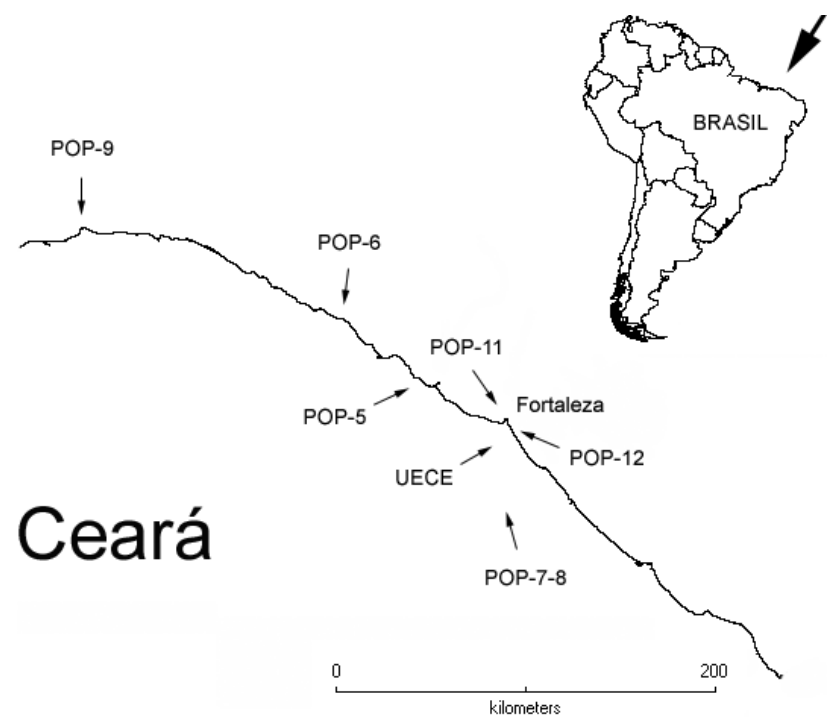

Fig. 1. Location of C. pygmaea populations along the coast of Ceará. "UECE" refers to populations on or near the campus of the University (POP-1, POP-2, POP-3; POP-4, POP-10).

Analyses of genetic diversity (number of alleles and private alleles, observed and expected heterozygosities, frequency of the most common allele) were calculated per locus for the eight populations using GeneAlex 6.2 software (Peakall \& Smouse, 2006).

To assess the genetic boundaries of the colonies, we used pair wise $F$ st values between nests. We assess these values between nests of the same colony, between colonies belonging to the same population and between colonies belonging to different populations.

All pair wise $F$ st values were calculated with SPAGeDi $1.2 \mathrm{~g}$ software (Hardy \& Vekemans, 2002). In addition, the index of relatedness (Queller \& Goodnight, 1989) was calculated within and between colonies sampled using SPAGeDi 1.2g software (Hardy \& Vekemans, 2002) and using all 16 genotyped colonies as reference populations.

Isolation by distance was estimated using GeneAlex 6.2 (Peakall \& Smouse, 2006) and GraphPad Instat 3.06 software (GraphPad Software, San Diego California USA) to determine whether there is a correlation between genetic and geographical distances.

\section{RESULTS}

High polygyny was observed in the colonies excavated during the present study (average number of queens per nest: mean $\pm \mathrm{SE}, 4.27 \pm 7.22$, range $=0-36, \mathrm{~N}=36$; at least 15 nests per colony), confirming the results reported previously by Quinet et al. (2009).

\section{Aggression tests}

During dyadic encounters in neutral arenas $(\mathrm{N}=220)$ aggressive interactions were never observed, whatever the origin of the two workers tested. However, the mean time spent in antennation was positively correlated with the geographical distance separating the colonies of the workers used in the bioassay (Pearson's $r=0.5987, p=$ 0.0397).

In field experiments, no aggressive behaviour was observed both in the control and during intra-colonial confrontations. In contrast, aggressive encounters were 


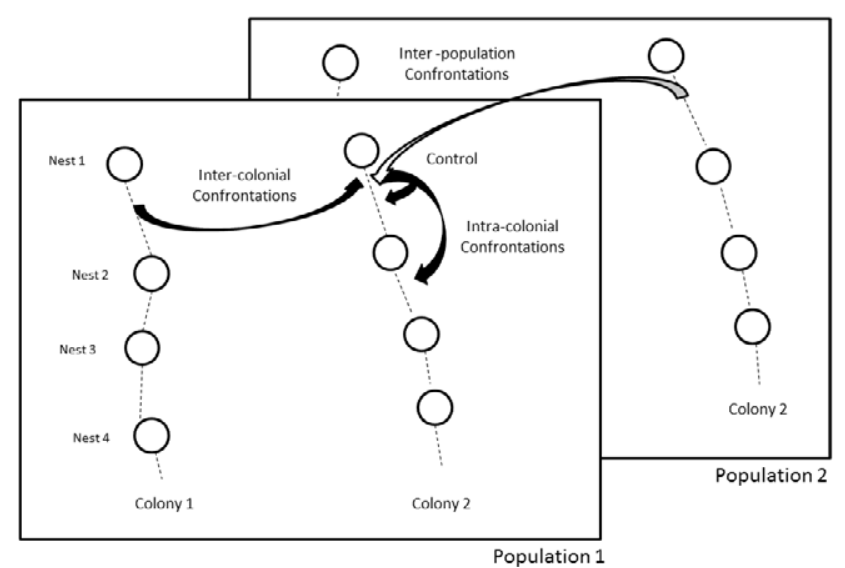

Fig. 2. Schematic representation of combinations of aggression tests carried out in the field between nests, between colonies and between populations.

frequent when a foreign worker was placed on a trail of a colony, with inter-population aggressiveness (percentage of aggressive encounters: mean $\pm \mathrm{SE}=90.50 \pm 11.41, \mathrm{~N}$ $=10$ ) being significantly higher than inter-colonial (but intra-population) aggressiveness (percentage of aggressive encounters: mean $\pm \mathrm{SE}=58.98 \pm 27.17, \mathrm{~N}=11$ ) (Mann-Whitney test, $p<0.0001$ ), at least with the reference colony used for estimating the inter-population aggressiveness.

\section{Chemical analyses}

GC/MS analyses of cuticular compounds revealed a mixture of linear and methyl-branched alkanes ranging from $\mathrm{C} 23$ to $\mathrm{C} 30$, as well as a few alkenes (Fig. 3).

All the cuticular profiles of the workers were very similar. However, similarity was significantly lower between colonies of different populations (mean Nei index \pm SD $=$ $0.938 \pm 0.0456 ;$ range $=0.714-0.995 ; \mathrm{N}=1701)$ than between colonies of the same population (mean Nei index $\pm \mathrm{SD}=0.971 \pm 0.020 ;$ range $=0.903-0.995 ; \mathrm{N}=108)$ (Mann-Whitney test, $p<0.001$ ). Nei index between colonies of the same population were also significantly different from those between nests of the same colony (mean $\pm \mathrm{SD}=0.980 \pm 0.017 ;$ range $=0.916-0.999 ; \mathrm{N}=82$ ) (Mann-Whitney test, $p<0.001)$. However, chemical distances (Nei index calculated by comparing the mean worker's chemical profile of different colonies) were not significantly correlated with geographical distances (Matrix correlation, $\mathrm{r}=-0.015$; Spearman's rank correlation coefficient, $p=0.882$ ).

\section{Microsatellite data analyses}

256 workers from eight populations were examined for microsatellite variation (Table 1). Each locus was successfully amplified for all individuals. All loci were polymorphic in the eight populations sampled, with the number of alleles per locus per population ranging from 1 to 10 . We thus used a total of 57 different alleles with an average of $2.37 \pm 1.18$ (mean $\pm \mathrm{SE}$ ) private alleles per population. All sequences were deposited in the GenBank Data Library.

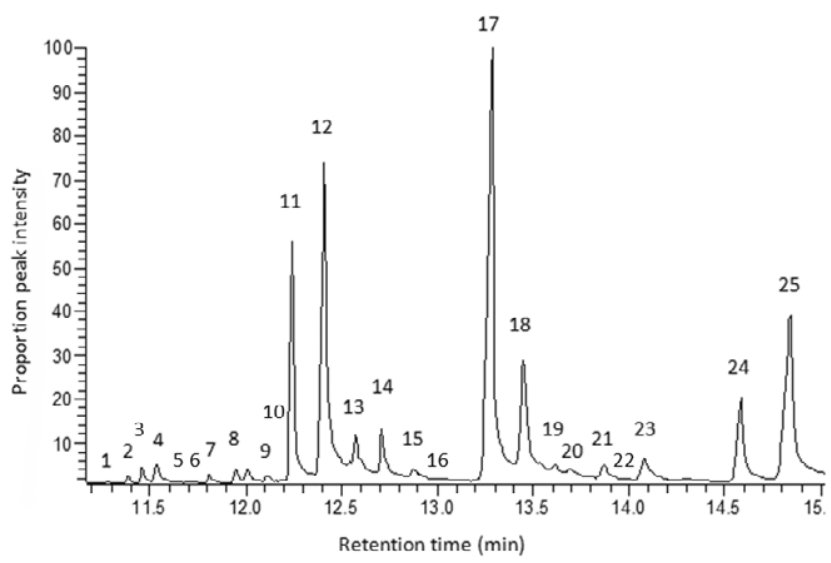

Fig. 3. GC chromatogram of cuticular hydrocarbons of $C$. pygmaea workers. $1: \mathrm{xC} 23: 1 ; 2: \mathrm{n}-\mathrm{C} 23 ; 3$ : unidentified hydrocarbon; 4: 9+11-MeC23; 5 and 6: unidentified hydrocarbons; 7: n-C24; 8: 10+12-MeC24; 9: xC25:1; 10: unidentified hydrocarbon; 11: $\mathrm{n}-\mathrm{C} 25 ; 12$ : 11+13-MeC25; 13: 3-MeC25; 14: n-C26; 15: 10+12-MeC26; 16: unidentified hydrocarbon; 17: n-C27; 18: 11+13-MeC27; 19: 5-MeC27; 20: 3-MeC27; 21: n-C28; 22: unidentified hydrocarbon; 23 : $10+12-\mathrm{MeC} 28 ; 24: \mathrm{n}-\mathrm{C} 29 ; 25$ : $11+13-\mathrm{MeC} 29$.

The level of observed heterozygosity per locus in Ceará populations varied from 0.188 to 0.813 (mean 0.500 ). All loci showed a significant heterozygote deficit (Table 1; Chi2: infinity, df: 32, $p<0.0001$ ) (Raymond \& Rousset 1995).

These departures from HWE could be due to presence of null alleles. However, null alleles are readily detected in this system by genotyping haploid males, and in a preliminary analysis of 16 males originating from different populations, all loci were amplified successfully in all individuals (data not shown). Moreover, the four loci were successfully amplified for all workers genotyped. Thus, it is likely that null alleles are not present at a high frequency in any of the new loci. In addition, there are other biological explanations that are likely to explain the observed homozygote excess.

Workers from nests of the same colony were not genetically different (mean $F$ st $=0.0181 \pm 0.1067$, Wilcoxon rank sum test, $p=0.7317, d f=26$ ), while workers from different colonies and/or populations were genetically differentiated (respectively, mean $F$ st $=0.3997 \pm$ 0.2099, Wilcoxon rank sum test, $p<0.0001, d f=38$; mean $F$ st $=0.4702 \pm 0.1194$, t test, $p<0.0001, d f=562$ ). On average, the genetic distance between two workers from two different colonies from the same population was significantly different from the genetic distance between two workers from different populations (Mann-Whitney test, $p=0.0202)$. In addition, intra-colonial relatedness was higher (mean $r=0.5843 \pm 0.0449$ ) than relatedness between colonies (Wilcoxon rank sum test, $p<0.0001$; mean $r=-0.0038 \pm 0.0006)$.

Neighbouring colonies tend to be more genetically similar than more distant colonies, as shown by a relatively strong and significant isolation by distance (Matrix correlation, $r=0.3162$; Mantel test with Spearman's rank correlation coefficient, $p=0.0004$ ). In contrast, genetic 
TABLE 1. Description of the microsatellites developed for Crematogaster pygmaea. $\mathrm{N}_{\mathrm{a}}$ - the number of alleles, $\mathrm{H}_{0}-$ estimates of observed, $\mathrm{H}_{\mathrm{e}}$ - expected heterozygosities, Freq (A) - frequency of the most common allele. The calculations are based on 32 individuals per population, two colonies per population (16 individuals per colony).

\begin{tabular}{|c|c|c|c|c|c|c|c|c|c|c|c|}
\hline Locus & & Primer sequences $\left(5^{\prime}-3^{\prime}\right)$ & $\begin{array}{c}\text { Repeat } \\
\text { motif }\end{array}$ & Size $(b p)$ & $\mathrm{N}_{\mathrm{a}}$ & Populations & $\mathrm{N}_{\mathrm{a}}$ & $\mathrm{H}_{\mathrm{o}}$ & $\mathrm{H}_{\mathrm{e}}$ & Freq $(A)$ & $\begin{array}{c}\text { Accession } \\
\text { no. }\end{array}$ \\
\hline \multirow{8}{*}{ Cpyg1 } & $\mathrm{F}:$ & GAAACAACATATAACGTTAAG & $(\mathrm{AC})_{21}$ & $138-160$ & 7 & POP-1 & 3 & 0.500 & 0.562 & 0.578 & GQ183015 \\
\hline & $\mathrm{R}:$ & GGTAAGACTAGTTTCAGGAA & & & & POP-2 & 2 & 0.250 & 0.305 & 0.813 & \\
\hline & & & & & & POP-3 & 2 & 0.250 & 0.404 & 0.719 & \\
\hline & & & & & & POP-4 & 4 & 0.469 & 0.410 & 0.750 & \\
\hline & & & & & & POP-5 & 4 & 0.531 & 0.673 & 0.359 & \\
\hline & & & & & & POP-6 & 2 & 0.188 & 0.219 & 0.875 & \\
\hline & & & & & & POP-7 & 3 & 0.333 & 0.509 & 0.550 & \\
\hline & & & & & & POP-8 & 6 & 0.563 & 0.723 & 0.344 & \\
\hline \multirow{8}{*}{ Cpyg2 } & F: & CCATCCTTTGTCCCGATTTT & $(\mathrm{CA})_{28}$ & $190-230$ & 13 & POP-1 & 5 & 0.594 & 0.666 & 0.438 & GQ183014 \\
\hline & & ATCGAATTTTTGTCGACGTG & & & & POP-2 & 3 & 0.344 & 0.48 & 0.625 & \\
\hline & & & & & & POP-3 & 5 & 0.563 & 0.697 & 0.422 & \\
\hline & & & & & & POP-4 & 6 & 0.594 & 0.799 & 0.266 & \\
\hline & & & & & & POP-5 & 4 & 0.375 & 0.726 & 0.375 & \\
\hline & & & & & & POP-6 & 3 & 0.313 & 0.625 & 0.500 & \\
\hline & & & & & & POP-7 & 5 & 0.531 & 0.645 & 0.531 & \\
\hline & & & & & & POP-8 & 6 & 0.375 & 0.635 & 0.563 & \\
\hline \multirow{8}{*}{ Cpyg3 } & F: & GCATTCAGGTCATTTTCAAG & $(\mathrm{TG})_{21}$ & $250-288$ & 15 & POP-1 & 1 & 0.000 & 0.000 & 1.000 & GQ183016 \\
\hline & & ACCTACGAAACATGTGAGTG & & & & POP-2 & 5 & 0.419 & 0.598 & 0.484 & \\
\hline & & & & & & POP-3 & 3 & 0.313 & 0.521 & 0.625 & \\
\hline & & & & & & POP-4 & 5 & 0.323 & 0.644 & 0.452 & \\
\hline & & & & & & POP-5 & 3 & 0.344 & 0.380 & 0.766 & \\
\hline & & & & & & POP-6 & 3 & 0.219 & 0.626 & 0.438 & \\
\hline & & & & & & POP-7 & 5 & 0.281 & 0.630 & 0.547 & \\
\hline & & & & & & POP-8 & 4 & 0.313 & 0.591 & 0.500 & \\
\hline \multirow[t]{8}{*}{ Cpyg4 } & F: & AAGTGCGTGGTGAAACCTAA & $(\mathrm{GA})_{36}$ & $202-298$ & 22 & POP-1 & 8 & 0.500 & 0.820 & 0.266 & GQ183017 \\
\hline & & GGGACGTAAGCATTGTACC & & & & POP-2 & 5 & 0.594 & 0.597 & 0.453 & \\
\hline & & & & & & POP-3 & 6 & 0.188 & 0.665 & 0.500 & \\
\hline & & & & & & POP-4 & 10 & 0.581 & 0.851 & 0.226 & \\
\hline & & & & & & POP-5 & 6 & 0.469 & 0.703 & 0.438 & \\
\hline & & & & & & POP-6 & 6 & 0.563 & 0.752 & 0.344 & \\
\hline & & & & & & POP-7 & 7 & 0.594 & 0.782 & 0.328 & \\
\hline & & & & & & POP-8 & 10 & 0.813 & 0.850 & 0.219 & \\
\hline
\end{tabular}

distances were not significantly correlated with chemical distances (matrix correlation, $\mathrm{r}=0.1831$; Mantel test with Spearman's rank correlation coefficient, $p=0.0823$ ).

\section{DISCUSSION}

Our results show that, although highly polygynous and polydomous, C. pygmaea is clearly a multicolonial species, at least in the study area. Colony boundaries, firstly estimated by observing the movements of workers between nests, were confirmed by genetic, behavioural and chemical data. Aggression was never observed between workers from different nests belonging to the same colony. By contrast, workers were very aggressive towards individuals from other colonies they encountered on their network of trails. Genetic boundaries were also very clear since we found no genetic differences between nests of the same colony whereas there were significant differences between colonies in the same population and between different populations. Profiles of cuticular hydrocarbons were very similar whatever the origin of the workers sampled, but chemical distances were significantly greater between workers of different populations or colonies than between workers of different nests of the same colony.

Due to a greater diversity in olfactory receptors and recognition cues of genetic origin, workers from polygynous colonies are expected to be less efficient in nestmate recognition (Bourke \& Franks, 1995). This should be particularly true for highly polygynous species, in which non-aggression between distant colonies is reported (e.g. Tsutsui et al., 2000; Holway et al., 2002). Here, we show that workers of the highly polygynous species $C$. pygmaea can discriminate between nestmate and nonnestmate workers, and behave aggressively towards the latter, as recently described for several other highly polygynous ant species (e.g. M. rubra in Maine populations: Garnas et al., 2007; D. mariae: Laskis \& Tschinkel, 2008; Plagiolepis pygmaea: Thurin \& Aron, 2008). These results are of particular interest in C. pygmaea, D. mariae and $P$. pygmaea because high polygyny in these species is not associated with unicoloniality or supercolony structures (sensu Helanterä et al., 2009), as is the case for example in L. humile (Suarez et al., 1999; Tsutsui et al., 2000; Pedersen et al., 2006), Anoplolepis gracilipes 
(Abbott et al., 2007; Drescher et al., 2007) or L. neglectus (Ugelvig et al., 2008). Therefore, they represent rare examples of native species forming highly polygynous and territorial colonies.

The combination of such traits as high polygyny and territoriality in $C$. pygmaea could be explained by a strong relatedness among queens within the same colony leading to a low genetic diversity among workers of the same colony, as described in P. pygmaea (Trontti et al., 2005). However, the absence of a simple correlation between genetic diversity and nestmate recognition is reported in two other native species, $F$. paralugubris (Chapuisat et al., 2005; Holzer et al., 2006) and F. selysi (Rosset et al., 2007). Although the former is unicolonial and the second is territorial, both species are polygynous and their ability to recognize nestmates is associated with low relatedness between worker nestmates (Chapuisat et al., 1997; Rosset et al., 2007). Therefore, the relationship between the number of queens, genetic diversity, recognition ability and territoriality in ants is clearly more complex than previously thought.

Although it is well known that animal behaviour is largely context dependent (Liebert \& Starks, 2004; Buczkowski \& Silverman, 2005; Campbell et al., 2009; Helanterä, 2009), aggressiveness in ants is generally estimated using basic bioassays. Simple dyadic encounters in neutral arenas are often used for this purpose (e.g. Dahbi et al., 1996; Tsutsui et al., 2000; Giraud et al., 2002; Fournier et al., 2009). Few studies compare results obtained in the laboratory and the field (Campbell et al., 2009; d'Ettorre \& Lenoir, 2010) or using different bioassays (Roulston et al., 2003). Here, we clearly show that aggressiveness between $C$. pygmaea workers from different colonies, although unambiguously observed in the field, can not be detected by dyadic encounters in Petri dishes. Moreover, recent studies demonstrate that subtle behaviour, such as rates of trophallaxis or time spent in antennation, may reveal the presence of nestmate recognition even in the absence of clear aggressiveness (Steiner et al., 2007; Chapuisat et al., 2005; Holzer et al., 2006; Björkman-Chiswell et al., 2008). Our study therefore clearly demonstrates that tests of aggression between pairs of workers recorded in neutral arenas are insufficient to accurately assess nestmate recognition or aggressiveness between ant colonies.

Alkenes and branched alkanes are generally expected to encode stable signals used in nestmate recognition in ants (Dani et al., 2001; Howard \& Blomquist, 2005; Lucas et al., 2005; Guerrieri et al., 2009; Brandt et al., 2009; Martin et al., 2009). In C. pygmaea, only 10 methyl alkanes and 2 alkenes were identified. However, this seems sufficient to ensure colonial identity, as suggested by both empirical (Breed, 1998; Boulay et al., 2000; Dani et al., 2001) and theoretical studies (Breed \& Buchwald, 2009).

Our data show that $C$. pygmaea colonies belonging to the same population were genetically differentiated and that genetic differentiation was correlated with geographical distances. These results suggest that populations are spatially isolated and that gene flow between them is low. This could be due both to the limited dispersal of sexuals during the nuptial flights observed in this species (Quinet et al., 2009) and to frequent nest budding events (Crozier \& Pamilo, 1996; Chapuisat et al., 1997). We also show that chemical and genetic distances were not correlated, a result that contrasts with that reported for the Argentine ant and two species of Lasius (Vogel et al., 2009; Cremer et al., 2008). Such a correlation, however, is not confirmed for Lasius neglectus (Ugelvig et al., 2008). A strong association between these two parameters is expected only if the chemical diversity of cuticular compounds is directly correlated with the overall genetic distance estimated using microsatellite marker loci. Although it is well known that chemical recognition cues have a genetic component, environmental conditions can also affect cuticular profiles (d'Ettorre \& Lenoir, 2010), breaking the correlation between genetic and chemical distances. However, our results should be interpreted with caution given that the estimate of genetic distance was based only on 4 microsatellite loci.

In conclusion, no support was found in this study for the hypothesis that high polygyny should lead to limited recognition abilities between ant colonies. Although polydomous, C. pygmaea does not form super colonies (sensu Helanterä et al., 2009) since direct interactions between workers from the different nests belonging to the same colony are possible. Therefore, the most important finding of the present work is that high polygyny does not necessarily lead to large supercolonial structures extending over great distances but, on the contrary, that highly polygynous ant species can form territorially and genetically well-defined entities showing a clear multicolonial organisation at a local scale. A detailed analysis of the genetic structure of $C$. pygmaea colonies, currently under progress in our laboratory, should help us to understand the possible role of nestmate relatedness in the social closure of this species.

ACKNOWLEDGEMENTS. We thank P. Mardulyn, O. Hardy and G. Dauby for their help and advice, and L. Grumiau for technical advice. This work was supported by several grants from the Belgian "Fond National de la Recherche Scientifique (FNRS)" to R. Hamidi and J.-C. de Biseau, and by grants 473939/2004-5 and DCR 303605/2003-0 from the Brazilian "Conselho Nacional de Desenvolvimento Científico e Tecnológico (CNPq)" to Y. Quinet and A. Heredia, respectively.

\section{REFERENCES}

Abbott K.L., Greaves S.N.J., Ritchie P.A. \& Lester P.J. 2007: Behaviourally and genetically distinct populations of an invasive ant provide insight into invasion history and impacts on a tropical ant community. Biol. Invas. 9: 453-463.

Bü̈rkman-Chiswell B.T., van Wilgenburg E., Thomas M.L., Swearer S.E. \& Elgar M.A. 2008: Absence of aggression but not nestmate recognition in an Australian population of the Argentine ant Linepithema humile. Insectes Soc. 55: 207-212.

Boulay R., Hefetz A., Soroker V. \& Lenoir A. 2000: Camponotus fellah colony integration: worker individuality necessitates frequent hydrocarbons exchanges. Anim. Behav. 59: 1127-1133. 
Bourke A.F.G. \& Franks N.R. 1995: Social Evolution in Ants. Princeton University Press, Princeton, 529 pp.

Brandt M., van Wilgenburg E. \& Tsutsui N.D. 2009: Globalscale analyses of chemical ecology and population genetics in the invasive Argentine ant. Mol. Ecol. 18: 997-1005.

BREED M.D. 1998: Chemical cues in kin recognition: criteria for identification, experimental approaches, and the honey bee as an example. In Vander Meer R.K., Breed M.D., Winston M.L. \& Espelie K.E. (eds): Pheromone Communication in Social Insects. Westview Press, Boulder, pp. 126-155.

Breed M.D \& Buchwald R. 2009: Cue diversity and social recognition. In Gadau J. \& Fewell J. (eds): Organization of Insect Societies - From Genome to Sociocomplexity. Harvard University Press, Cambridge, MA, pp. 173-193.

Buczkowski G. \& Silverman J. 2005: Context-dependent nestmate discrimination and the effect of action thresholds on exogenous cue recognition in the Argentine ant. Anim. Behav. 69: 741-749.

Campbell D.L.M., Weiner S.A., Starks P.T. \& Hauber M.E. 2009: Context and control: behavioural ecology experiments in the laboratory. Ann. Zool. Fenn. 46: 112-123.

Chapuisat M., Bernasconi C., Hoenn S. \& Reuter M. 2005 Nestmate recognition in the unicolonial ant Formica paralugubris. Behav. Ecol. 16: 15-19.

Chapuisat M., Goudet J. \& Keller L. 1997: Microsatellites reveal high population viscosity and limited dispersal in the ant Formica paralugubris. Evolution 51: 475-482.

Cremer S., Ugelvig L.V., Drijfhout F.P., Schlick-Steiner B.C., Steiner F.M., Seifert B., Hughes D.P., Schulz A., Petersen K.S., Konrad H., Stauffer C.K.K., Espadaler X., D’Ettorre P., Aktaç N., Eilenberg J., Jones G.R., Nash D.R., Pedersen J.S. \& Boomsma J.J. 2008: The evolution of invasiveness in garden ants. PLOS ONE 3: 1-9.

Crozier R.H. \& Pamilo P. 1996: Evolution of Social Insect Colonies, Sex Allocation and Kin-Selection. Oxford University Press, Oxford, $306 \mathrm{pp}$.

Dahbi A., Cerdá X., Hefetz A. \& Lenorr A. 1996: Social closure, aggressive behavior, and cuticular hydrocarbon profiles in the polydomous ant Cataglyphis iberica (Hymenoptera, Formicidae). J. Chem. Ecol. 22: 2173-2186.

Dani F.R., Jones G.R., Destri S., Spencer S.H. \& Turillazzi S. 2001: Deciphering the recognition signature within the cuticular chemical profile of paper wasps. Anim. Behav. 62: $165-171$.

Debout G., Schatz B., Elias M. \& Mckey D. 2007: Polydomy in ants: what we know, what we think we know, and what remains to be done. Biol. J. Linn. Soc. 90: 319-348.

D'EtTorre P. \& Lenoir A. 2010: Nestmate recognition in ants. In Lach L., Parr C. \& Abbott K. (eds): Ant Ecology. Oxford University Press, Oxford, pp. 194-209.

Drescher J., Blüthgen N. \& FeldhaAr H. 2007: Population structure and intraspecific aggression in the invasive ant species Anoplolepis gracilipes in Malaysian Borneo. Mol. Ecol. 16: $1453-1465$.

Drescher J., Blüthgen N., Schmitt T., Bühler J. \& FeldhaAR H. 2010: Societies drifting apart? Behavioral, genetic and chemical differentiation between neighboring supercolonies in the yellow crazy ant Anoplolepis gracilipes. PLOS ONE 5: e13581.

Forel A. 1904: Miscellanea myrmécologiques. Rev. Suisse Zool. 12: 1-52.

Fournier D., De Biseau J.C. \& Aron S. 2009: Genetics, behaviour and chemical recognition of the invading ant Pheidole megacephala. Mol. Ecol. 18: 186-199.

Garnas J.R., Drummond F.A. \& Groden E. 2007: Intercolony aggression within and among local populations of the inva- sive ant, Myrmica rubra (Hymenoptera: Formicidae), in coastal Maine. Environ. Entomol. 36: 105-113.

Giraud T., Pedersen J.S. \& Keller L. 2002: Evolution of supercolonies: The argentine ants of southern Europe. Proc. Natl. Acad. Sci. 99: 6075-6079.

GlenN T.C. \& Schable N.A. 2005: Isolating microsatellite DNA loci. Methods Enzymol. 395: 202-222.

Guerrieri F.J., Nehring V., Jorgensen C.G., Nielsen J., Galizia C.G. \& D'Ettorre P. 2009: Ants recognize foes and not friends. Proc. R. Soc. Lond. (B) 276: 2461-2468.

HAMILTON W.D. 1964a: The genetical evolution of social behaviour. I. J. Theor. Biol. 7: 1-16.

HAMILTON W.D. 1964b: The genetical evolution of social behaviour. II. J. Theor. Biol. 7: 17-52.

HaRdY O.J. \& VeKemans X. 2002: SPAGeDi: a versatile computer program to analyse spatial genetic structure at the individual or population levels. Mol. Ecol. Notes. 2: 618-620.

Helanterä H. 2009: Do unicolonial wood ants favor kin? $J$. Biol. 8: 1-5.

Helanterä H., Strassmann J.E., Carrillo J. \& Queller D.C. 2009: Unicolonial ants: where do they come from, what are they and where are they going? Trends Ecol. Evol. 24: 341-349.

Holway D.A., Lach L., Suarez A.V., Ysutsui N.D. \& Case T.J. 2002: The causes and consequences of ant invasions. Annu. Rev. Ecol. Syst. 33: 181-233.

Holzer B., Chapuisat M., Kremer N., Finet C. \& Keller L. 2006: Unicoloniality, recognition and genetic differentiation in a native Formica ant. J. Evol. Biol. 19: 2031-2039.

Howard R.W. \& BLOMQUist G.J. 2005: Ecological, behavioral, and biochemical aspects of insect hydrocarbons. Annu. Rev. Entomol. 50: 371-393.

KeLLER L. 1995: Social life: the paradox of multiple-queen colonies. Trends Ecol. Evol. 10: 355-360.

Keller L. \& Passera L. 1989: Influence of the number of queens on nestmate recognition and attractiveness of queens to workers in the Argentine ant, Iridomyrmex humilis (Mayr). Anim. Behav. 37: 733-740.

Laskis K.O. \& Tschinkel W.R. 2008: The seasonal natural history of the ant, Dolichoderus mariae, in northern Florida. $J$. Insect Sci. 9: 1-26.

Liebert A.E. \& Starks P.T. 2004: The action component of recognition systems: a focus on the response. Ann. Zool. Fenn. 41: 747-764.

Lucas C., Pho D.B., Jallon J.M. \& Fresneau D. 2005: Role of cuticular hydrocarbons in the chemical recognition between ant species in the Pachycondyla villosa species complex. $J$. Insect Physiol. 51: 1148-1157.

Marlier J.F., Quinet Y. \& De Biseau J.C. 2004: Defensive behaviour and biological activities of the abdominal secretion in the ant Crematogaster scutellaris (Hymenoptera: Myrmicinae). Behav. Processes 67: 427-444.

Martin S. \& DriJfhout F. 2009: A review of ant cuticular hydrocarbons. J. Chem. Ecol. 35: 1151-1161.

Morel L., Vander Meer R.K. \& Lofgren C.S. 1990: Comparison of nestmate recognition between monogyne and polygyne populations of Solenopsis invicta (Hymenoptera: Formicidae). Ann. Entomol. Soc. Am. 83: 642-647.

PASSERA L. 1994: Characteristics of tramp species. In Williams D.F. (eds): Exotic Ants: Biology, Impact, and Control of Introduced Species. Westview Press, Boulder, pp. 23-43.

Peakall R. \& Smouse P.E. 2006: GENALEX 6: genetic analysis in Excel. Population genetic software for teaching and research. Mol. Ecol. Notes 6: 288-295. 
Pedersen J.S., Krieger M.J.B., Vogel V., Giraud T. \& Keller L. 2006: Native supercolonies of unrelated individuals in the invasive argentine ant. Evolution 60: 782-791.

Provost E. \& Cerdan P. 1990: Experimental polygyny and colony closure in the ant Messor barbarus (L.) (Hymenoptera: Formicidae). Behaviour 115: 114-126.

Queller D.C. \& GoodNight K.F. 1989. Estimating relatedness using genetic markers. Evolution 43: 258-275.

Quinet Y., Tekule N. \& De Biseau J.C. 2005: Behavioural interactions between Crematogaster brevispinosa rochai Forel (Hymenoptera: Formicidae) and two Nasutitermes species (Isoptera: Termitidae). J. Insect Behav. 18: 1-17.

Quinet Y., Hamidi R., Ruiz-Gonzalez M.X., de Biseau J.C. \& LongINo J.T. 2009: Crematogaster pygmaea (Hymenoptera: Formicidae: Myrmicinae), a highly polygynous and polydomous Crematogaster from northeastern Brazil. Zootaxa 2075: $45-54$.

Raymond M. \& Rousset F. 1995: Genepop (Version-1.2) Population-genetics software for exact tests and ecumenicism. J. Hered. 86: 248-249.

Rosset H., Schwander T. \& Chapuiset M. 2007: Nestmate recognition and levels of aggression are not altered by changes in genetic diversity in a socially polymorphic ant. Anim. Behav. 74: $951-956$.

Roulston T.H., Buczkowski G. \& Silverman J. 2003: Nestmate discrimination in ants: effect of bioassay on aggressive behavior. Insectes Soc. 50: 151-159.

SAMBrooK J., Fritsch E.F. \& Maniatis T. 1989: Molecular Cloning: A Laboratory Manual. Cold Spring Harbor Laboratory Press, New York, 1659 pp.

Sandrock C., Frauenfelder N., Von Burg S. \& Vorburger C. 2007: Microsatellite DNA markers for the aphid parasitoid Lysiphlebus fabarum and their applicability to related species. Mol. Ecol. Notes. 7: 1080-1083.

SATOH T. \& HiROTA T. 2005: Factors affecting internest variation in the aggressiveness of a polygynous ant, Camponotus yamaokai. Entomol. Sci. 8: 277-281.
SchrempF A.R.C., Tinaut A. \& Heinze J. 2005: Inbreeding and local mate competition in the ant Cardiocondyla batesii. Behav. Ecol. Sociobiol. 57: 502-510.

Starks P.T., Watson R.E., Dipaola M.J. \& Dipaola C.P. 1998: The effect of queen number on nestmate discrimination in the facultatively polygynous ant Pseudomyrmex pallidus (Hymenoptera: Formicidae). Ethology 104: 573-584.

Steiner F.M., Schlick-Steiner B.C., Moder K., Stauffer C., Arthofer W., Buschinger A., Espadaler X., Christian E., Einfinger K., Lorbeer E., Schafellner C., Ayasse M. \& CROZIER R.H. 2007: Abandoning aggression but maintaining self-nonself discrimination as a first stage in ant supercolony formation. Curr. Biol. 17: 1903-1907.

StUART R.J. 1991: Nestmate recognition in leptothoracine ants: testing for effects of queen number, colony size and species of intruder. Anim. Behav. 42: 277-284.

Suarez A.V., Tsutsui N.D., Holway D.A. \& Case T.J. 1999: Behavioral and genetic differentiation between native and introduced populations of the Argentine ant. Biol. Invas. 1: 43-53.

Thurin N. \& Aron S. 2008: Seasonal nestmate recognition in the polydomous ant Plagiolepis pygmaea. Anim. Behav. 75: 1023-1030.

Trontti K., Aron S. \& Sundstrom L. 2005: Inbreeding and kinship in the ant Plagiolepis pygmaea. Mol. Ecol. 14: 2007-2015.

Tsutsui N.D., Suarez A.V., Holway D.A. \& Case T.J. 2000: Reduced genetic variation and the success of an invasive species. Proc. Nat. Acad. Sci. U.S.A. 97: 5948-5953.

Ugelvig L.V., Drijfhout F.P., Kronauer D.J.C., Boomsma J.J., Pedersen J.S. \& CREMER S. 2008: The introduction history of invasive garden ants in Europe: integrating genetic, chemical and behavioural approaches. BMC Biol. 6: 1-14.

Vogel V., Pedersen J.S., D’Ettorre P., Lehmann L. \& Keller L. 2009: Dynamics and genetic structure of Argentine ant supercolonies in their native range. Evolution 55: 2131-2136.

Received November 25, 2010; revised and accepted August 26, 2011 